\title{
PERKEMBANGAN TEATER MODERN BERBASIS TRADISI DI KOTA PADANGPANJANG
}

\author{
Atika Raystifa \\ Program Pascasarjana, Pengkajian Seni Teater \\ Institut Seni Indonesia Padangpanjang \\ Padangpanjang , Sumatra Barat \\ E-mail : atikararey22@gmail.com
}

\begin{abstract}
Abstrak
Penelitian terhadap perkembangan teater modern berbasis tradisi di kota Padangpanjang,merupakan upaya untuk meneliti bagaimana perkembangan teater modern berbasis tadisi dikota Padangpanjang dan apa factor-fator yang menyebabkan teater modern berbasis tradisi berkembang. Upaya untuk melakukan penelitian berikut diawali dengan meneliti dua komunitas teater modern yang menjadikan tradisi sebagai pijakannya di kota padang panjang dan melakukan kajian atas factor-faktor yang menyebabkan perkembangan teater modern berbasis tradisi pada dua komunitas tersebut. Penelitian dilanjutkan dengan melakukan survei kepada 2 komunitas teater yang aktif pada saat ini di kota Padangpanjang dan narasumber yang pernah menonton atau melihat pertunjukan teater modern berbasis tradisi dan menyimpulkan terhadap tanggapan yang di berikan para narasumber tersebut. Penelitian ditulis dengan hasil survei tersebut sesuai dengan fakta.
\end{abstract}

Kata Kunci: Teater Modern berbasis tradisi; Perkembangan; Kota Padangpanjang.

\begin{abstract}
Research on the development of modern theatre based tradition in Padangpanjang City, is an effort to examine how the modern theatre development is based in Padangpanjang City and what are the factors that led to modern theater based Tradition develops. The effort to do the following research begins by researching two modern theatre communities that make a tradition as a stage in the Padang city and study the factors that led to the development of modern-based theatre Traditions of the two communities. The research continued by conducting surveys to the 2 active theatre communities at this time in the city of Padangpanjang and the sources that have been watching or seeing modern theater-based performances of traditions and concluded against the responses Give the speakers. Research is written with the results of the survey in accordance with the facts.
\end{abstract}

Keywords: modern theatre-based traditions, developments, city of Padangpanjang.

\section{PENDAHULUAN}

Wilayah Indonesia adalah wilayah yang kaya dengan pulau-pulau serta suku bangsanya, dan juga kaya dengan seni teater yang telah dikenal. Randai, lenong, ketoprak merupakan teater tradisional yang kekuatan daya hidupnya terhabtung pada kebesaran budaya dan yang mendukungnya. Teater tradisional tak bisa lepas dari wilayah atau lingkungan yang menghidupinya baik yang sudah tersentun teater modern maupun tidak.

Kehadiran seni pertunjukan teater modern di Indonesia tidak terlepas dari sejarah kehadiran seni pertunjukan teater di Indonesia. Istilah modern merujuk pada situasi dalam ruang dan waktu masa kini. Hal ini merupakan cara menunjuk adanya perkembangan dan perubahan teater di 
daerah-daerah menjadi bentuk teater kekinian yang bercita rasa Indonesia. Artinya terjadi pergeseran konteks cipta, rasa, karsa, dari kehendak seniman yang bersifat tradisional menjadi kehendak yang bersifat nasional.

Jacob Sumardjo, mengatakan: Teater modern Indonesia adalah produk orangorang kota, diciptakan oleh penduduk kota dan untuk penduduk kota. Hal ini amat berbeda dengan bentuk-bentuk teater tradisional sebelumnya. Pada dasarnya bentuk teater modern merupakan hasil dari pengaruh kesenian modern Barat di kota-kota (1997: 99).

Istilah tradisional diartikan sebagai pertunjukan teater yang sesuai dengan tradisi, yaitu sesuai dengan kerangka pola bentuk maupun pola penerapan yang selalu berulang. Artinya, identitas pertunjukan teater tradisional di Indonesia adalah pertunjukan yang terkait tradisi. Tradisi di Indonesia yang dibentuk melalui gagasan tradisionalisme. Pertunjukan tradisional merupakan bagian dari pengalaman nyata seniman tradisional di Indonesia.

Jakob Sumardjo dan Saini K.M mengatakan, "Bahwa teater bertolak dari teater modern Barat namun dalam perkembangannya semakin dipengaruhi dan memanfaatkan teater daerah/tradisional sebagai sumber" (1998:59)

Setiap perwujudan bentuk dan isi teater, memiliki ciri-ciri bentuk dengan kecenderungan-kecenderungannya yang khas. Perkembangan, perwujudan teater mengalami indentifikasi hingga menjadi genre teater. Oleh karena itu, terjadinya perubahan di berbagai bentuk teater. Bentuk teater yang sudah ada kemudian dianggap tidak lagi memadai untuk menjawab kebutuhan teater di zamannya.
Seniman teater selalu bereaksi terhadap bentuk teater yang sudah ada itu dan melahirkan suatu bentuk teater yang baru. Proses perkembangan yang terjadi di Indonesia menyebabkan teater-teater tradisonal bertransformasi menjadi bentuk-bentuk teater baru. Kebaruan teater tersebut pada masanya mengikuti konvensi dari Barat. Hasil dari proses silang budaya inilah yang menjadi cikal bakal lahirnya teater modern yang ada di Indonesia. Perkembangan teater tradisional mulai terkikis ciri khas ketradisionalnya, sebagai akibat akulturasi budaya teater modren. Namun ada juga komunitas yang yang menjadikan tradisi sebagai landasan dalam mengembangkan teater modern.

Sahrul N, mengatakan: Teater modern yang ada di Sumatra Barat merupakan teater yang berkembang yang diakibatkan interaksi budaya antara Minangkabau dengan budaya kota besar. Sumatra Barat sebagai wilayah administrative masuk dalam wilayah budaya Minangkabau $(2015 ; 5)$

KotaPadangpanjang memiliki beberapa Komunitas Teater seperti PLONG, Bandar peran, Akar, KTM, RIMA, IPS, Teater Tambologi, teater sakata, komunitas hitam putih, dan komunitas seni kuflet. Sekian banyak komunitas yang berada di kota padangpanjang, terdapat komunitas yang berkembang dengan baik dan ada pula komunitas yang tidak produktif. Hal ini dibuktikan dengan aktifitas yang dilakukan dari tahun ke tahun yaitu adanya komunitas yang masih rutin mengadakan kegiatan latihan yang terjadwal. Sementara, ada pula komunitas yang selalu mengadakan aktivitas dan kreatifitas dalam pengembangan teater modern berbasis tradisi di kota padangpanjang. 
Sementara dalam kajian ini, ciri khas dalam membangun suasana penulis akan membatasi pada dua komunitas teater yang berkembang dengan pijakan dari tradisi yang menggambarkan dari sutradara atau pengkarya, di Padangpanjang yaitu Komunitas Seni Hitam Putih, dan Komunitas Seni Kuflet. Komunitas Hitam Putih berdiri pada tahun 1992 yang terkenal dengan nama teater plus, pada tanggal 31 oktober 1997 atas keputusan beberapa siswa dan alumni aktif teater plus berganti nama menjadi komunitas Hitam putih salah satu pendiri saat itu adalah

Yusril

(http://kelola.or.id/artist/komunitasseni-hitam-putih). 20.00 wib, 25 febuari 2019). Hitam putih, secara garis besar komunitas hitam putih sering menyajikan pertunjukan yang spektakuler, salah satu contohnya adalah "Tangga". Pertunjukan hitam putih juga mengkolaborasikan antara seni pertujukan dengan seni visual yang mana pada pertunjukan ini berpijak pada silat yang merupakan salah satu tradisi dari minangkabau.

Komunitas Seni Kuflet didirikan di Kota Padangpanjang pada 12 Mei 1997 oleh seniman, sastrawan dan tokoh seni diantaranya Prof. Dr. Mursal Esten, Dr. Sulaiman Juned S.Sn., M.Sn, Drs. Jufri, M.Sn, Wiko Antoni, S.Sn., M.Pd, Maizul, S. E, dan Netti Herawati S.S. Kuflet berasal dari bahasa Yunani, berarti bait dalam puisi, menyatukan antara satu baris dengan baris yang lain saling berhubungan. Jadi, Kuflet asalnya suatu kumpulan satu orang dengan orang lain sehingga membentuk kelompok yang memiliki tujuan sama, yaitu kekeluargaan, Komunitas seni Kuflet telah berdiri selama 22 tahun (komunitas kuflet).

Komunitas seni kuflet mempunyai

pertunjukannya,

mengembangkan

yaitu

dasar-dasar

dengan

tradisional Aceh, menjadi sebuah pertunjukan teater kontemporer. Komunitas seni kuflet pun lebih sering mengunakan Bahasa yang diplomatik. Pertunjukannya juga bersumber dari puisi atau karya sastra (naskah lakon) yang ditulis Sulaiman Juned. Komunitas Seni kuflet juga cenderung menampilkan pertunjukan dengan instrumen musiknya perkusi tubuh (tubuh aktornya), seperti petunjukan teater Hikayat Cantoi, Jambo Luka Tak Teraba, Jambo Beranak Duri dalam Daging, PM TOH Mencipta Bersama Masyarakat Karya/Sutradara Sulaiman Juned.

Penelitian dideskripsikan sebagai suatu proses investivigasi yang dilakukan dengan

Penelitian aktif, tekun, dan sistematis. menginterpretasikan, dan merevisi faktafakta. Berdasarkan penjelasan tersebut penulis berniat untuk meneliti perkembangan teater modern Indonesia berbasis tradisi di kota Padangpanjang.

Berdasarkan hal di atas penulis menjadi tertarik untuk melakukan penetian tentang perkembangan teater modern Indonesia berbasis tradisi di kota Padangpanjang. Informasi serta hasil Analisa dari penelitian tersebut dapat dijadikan sebagai dasar landasan melihat perkembangan teater di kota padangpanjang pada penelitian ini. Penelitian untuk mendapatkan berbagai pola aktifitas yang intensif dari komunitas teater di kota Padangpanjang.

Penulis tertarik untuk melakukan penelitian ini dikarenakan perkembangan teater modern Indonesia di Padangpanjang yang signifikan. Hal ini dibuktikan dengan adanya dua komunitas 
teater yang aktif yang telah terlibat pada kancah kancah nasional. Kehadiran dua Komunitas teater ini mampu membawa Padangpanjang ke kancah nasional, dan dua komunitas ini memiliki ciri khas dari kampung halaman penyaji atau sutradara yaitu tradisi minagkabau dan tradisi aceh.

\section{Metode}

Metode yang digukan adalah metode penelitian kuanlitatif, metode kualitatif digunakan karena beberapa pertimbangan. Pertama, penelitian kualitatif lebih mudah jika berhadapan dengan kenyataan ganda. Kedua, penelitian kualitatif menyajikan secara langsung hubungan peneliti dengan informan, dan ketiga penelitian kualitatif lebih peka dan lebih menyesuaikan diri pada pengaruh atas pola-pola nilai yang dihadapi. Berdasarkan beberapa alasan di atas maka, jenis penelitian kualitatif lebih sesuai digunakan untuk melihat secara langsung perkembangan teater modern Indonesia berbasis tradisi di kota padangpanjang.

\section{HASIL DAN PEMBAHASAN}

Indonesia adalah negara dengan kebudayaan yang beragam. Keanekaragaman tersebut dapat terlihat dari sebuah perjalanan panjang kehadiran pertujukan teater Indonesia. Pertunjukan teater Indonesia berkembang dengan menyerap elemen-elemen teater daerah sehingga munculnya teater modern berbasis tradisi. Teater Indonesia adalah teater adalah teater yang memakai bahasa Indonesia sebagai bahasa nasional. Berbeda dengan teater tradisional Indonesia yang memakai bahasa daerah daerah tertentu itu saja. Namun sebagai sebuah kebudayaan yang merupakan kebanggan bangsa Indonesia, teater tradisional tidak dapat dipisah dengan teater modern Indonesia untuk bahan penelitian ini adalah teater yang berangkat dari tradisi yang mendapat sentuhan barat. Teater ini adalah teater modern berbasis tradisi.

Sejarah perkembangan teater modern Indonesia dalam perjalanan diwarnai oleh berbagai gaya. Sementara pengaruh elemen-elemen teater daerah bergabung dalam suatu cara tertentu. Hal ini kemungkinan percampuran baru yang unik mengekspresikan ciri khas dari daerah atau kebudayaan yang ada di Indonesia. Kondisi tersebut menunjukan bahwa akar teater tradisi dan modern terus berpijak pada masyarakat maupun seniman yang membudidayakan pertujukan tersebut.

Pertumbuhan dan perkembangan teater dalam perkembangan teater dalam kehidupan masyrakat di Indonesia, tidak lepas dari pertumbuhan dan perkembangan kehidupan kesenian dan kebudayaan Indonesia yang terdiri dari berbagai suku bangsa, yang dengan sendirinya melahirkan kesenian yang sangat beragam yang bersumber dari kelainan budaya etnik setempat (Djelantik, 263:1999).

Berdasarkan pendapat di atas, teater Indonesia adalah suatu bentuk teater yang tumbuh dan berkembang di kota-kota besar sebagai bentuk kreatifitas dari seniman lokal bangsa Indonesia dalam persingungan dengan kebudayaan barat lewat teaternya. Hasil karya mempengaruh budaya lain, terutama secara teknis mengacu ke teater barat dengan tetap mengadaptasi pada keberadaan kebudayaan yang berakar pada teater tradisonal. Hal yang mengahadirkan teater modern Indonesia berbasis tradisi biasanya penagruh dari kampung halaman seniman itu sendiri. 
Sumatera

khususnya

kota

Padangpanjang, merupakan kota yang memiliki kampus seni tertua di Sumatera, yaitu ISI padang Panjang, pada tahun 1997 didirikan Jurusan Teater, hal inilah yang membuat munculnya dua komunitas berbasis tradisi. Komunitas tersebuat adalah Komunitas Seni Hitam Putih yang merupakan komunitas seni modern berbasis tradisi Minang dengan karya yang berjudul Tangga dan Komuitas Seni Kuflet yang merupakan komunitas modern berbasis tradisi Aceh dengan karya Hikayat Cantoi.

\section{Tangga}

Tangga adalah salah satu karya yusril yang merupakan bentuk dari teater modern berbasis tradisi, hal ini terlihat dari segi garapannya yang mengunakan budaya Minangkabau sebagai landasannya. Tangga terinspirasi dari seuah puisi karya iyut fitria dengan judul yang sama yaitu tangga. Puisi ini secara implisit merupakan kritik terhadap dualisme kekuasaan di Minangkabau.

Dualisme kekuasaan di Minangkabau dibangun dalam dua kelarasan yaitu Koto Piliang yang dipelopori oleh Datuk Katumanggungan dan Bodi Chaniago yang dipelopori oleh Datuk Parpatiah Nan Sabatang. Kelarasan Koto Piliang memiliki akar pada barjanjang naiak batangga turun, suatu sistem pemerintahan yang menitik dari langit, sebagai wujud sistem kekuasaan aristokrasi. Sementara, keselarasan Bodi Chaniago memiliki akar pada Duduak samo randah tagak samo tinggi, suatu sistem pemerintahan demokrasi Minangkabau yang lahir dari bawah.( Wawancara Afrizal Harun, 08 juli 2019 di ISI Padangpanjang).

Perbedaan prisip antara Koto Piliang dan Bodi Chaniago menjadi gagasan bagi yusri untuk menggarap karya dengan judul tangga. Aktor melakukan eksplorasi terhadap terhadap gagasan sutradara melalui wujud gerak tubuh di atas panggung. Kalimat-kalimat puisi di bagi pada setiap aktor yang sudah dipenggal dan disesuaikan dengan pengunaan property tangga, wujud akting yang dilakukan oleh para aktor menafsirkan gagasan sutradara melalui Bahasa tubuh (gestur, ekspresi dan vokal). Persoalan-persoalan perbedaan paham kekuasaan diangkat oleh Yusril dikarena hal ini sangat konteks dengan perbedaan paham kekuasaan secara lokal maupun universal. Yusril dapat dengan mudah menembus pasar teater dikarenakan garapan tangga sangat sesuai dengan isu saat itu maupun saat ini. Garapan ini pun menjadi semakin menarik dengan kemasan garapan mengunakan landasan modern berbasis tradisi. Pertunjukan tangga karya yusril ini merupakan bentuk perkembangan teater modern berbasis tradisi dikarena sang sutradara menghadirkan pola tradisi dalam bentuk modern. Karya tangga pun tidak lepas dari isu-isu yang beredar pun konteks dengan masyrakat saat ini.

\section{Proses Kreatif Tangga}

Proses kreatif tangga dimulai semejak tahun 2006 dan telah di pentas di beberapa tempat seperti denpasar pada 2125 november 2007, taman budaya sumbar 27 juli 2007, Gedung pertunjukan hoerojah adam isi padang Panjang 21 juli 2007, setelah dua pertunjukann ini ekplorasi terhadap tangga terus berlanjut, karena setiap pertunjukan akan selalu ada perkembangan, lalu pada pada tahun 20012 tangga kembali di pertujukan, yaitu pada, 27 september 2012 di stsi bandung,25 september 2012 taman izmail marzuki, 23 september 2012 taman budaya 
sumbar.

Garapan yang diinginkkan oleh sutradara adalah garapan yang bersifat Garapan bersifat eksperimental dan eksploratif. Fokus eksperimen adalah pada bentuk dan pemaknaan ulang terhadap naskah yang ditulis kemudian diterjemahkan ke dalam bentuk semiotika visual dan cendrung dekonstruktif.

Konsep akting dalam permainan, konsep akting yang digunakan adalah akting distorsi, dimana tubuh aktor tidak lagi menjadi tubuh yang sebenarnya tetapi telah dipengaruhi oleh tubuh sosial, tubuh biologi, tubuh budaya dan tubuhtubuh yang telah dipengaruhi oleh apa saja. Tubuh menjadi individu masingmasing yang terkontaminasi oleh persoalan apa saja. Makna yang ingin dicapai merupakan makna tak terhingga dalam pengertian bahwa pertunjukan ini bisa terfokus kemana saja tergantung pemahaman penonton dalam menilai karya ini secara objektif dan multiinterpretasi (Wawancara Afrizal Harun 19 juli 19.00 wib)

Pertunjukan yang bersifat eksprimental yang mengkolaborasikan system pemerintahan yang ada di Minangkabau di wujudkan dalam bentuk teater distorsi yang mana tubuh tidak lagi menajdi tubuh sebenarnya. Tubuh aktor adalah tubuh tanpa jenis kelamin, dia bisa menjadi tubuh sosial, tubuh budaya, tubuh akrobatik, tubuh tak terhingga dan tubuh ikonitas, tubuh ini menciptakan ruang makna yang beragam dalam diri masing masing aktor. Keinginan sutradara dalam menyampaikan maknan lewat tubuh merupakan suatu hal yang sangta menentukan.

Pertunjukan dengan bantuan property tangga berjumlah 8 buah sesuai dengan banyak aktor dari pertunjukan tersebut, guna tangga tersebut sangat beragam yaitu bisa menajdi penjara, Menara, pembatas, jembatan, bahkan keranda. Afrizal harun mengatakan (wawancara 19 juni 2019, 19.51. wib) peristiwa yang diambil dari mitos Minangkabau ini hanya sebagai alat untuk mengungkap sesuatu yang lebih universal. Peristiwa demokrasi tanpa judul ini diaktualisasikan dengan demokrasi secara menyeluruh yang ada di bumi ini. Peristiwa perang dengan segala akibatnya dan penjajahan peradaban oleh negara maju terhadap negara berkembang dan terbelakang, menjadi sorotan kemanusiaan karya ini. Bisa dilihat dalam dialog "di timur matahari akan terbit" bisa menjadi indikasi bahwa ada perlawanan keras terhadap hegemoni barat.

Minangkabau menjadi suatu referansi yang penting pada pertunjukan ini. Gerakan silat, Bahasa, tempat sirih (carano), dan hal lain yang bersifat budaya Minangkabau dalam seluruh peristiwa yang berkaitan dengan keselarasan demokrasi di minagkabau dan juga bersifat universal, adalah hal yang yang coba di pertahankan oleh sutradara dalam ranka memadukan struktur. Pertunjukan ini bisa di sebut lokal atau tradisi tapi maknamakna yang disampaikan pada pertunjukan ini tidak lagi bersifat lokal. Hal ini merupakan upaya untuk pencarian makna yang melampuai realitas. absurditas memberikan ruang untuk menjadikan teks naskah ini untuk kebutuhan teks pemanggungan yang lebih inovatif dan original. Inovasi yang akan terwujud adalah melalui metoda penyutradaraan yang representasi yaitu dengan melakukan penafrsiran ulang terhadap teks untuk kebutuhan panggung.

Karya yang berdurasi sekitar 55 menit ini, sejati memiliki etika 
konvensional, seperti ungkapan Bajanjang naik batanggo turun segalanya sesuatunya sudah ada aturannya dan tata caranya. Akan tetapi benturan akan muncul ketika situasi kekinian tidak lagi tertampung dalam koridor adat. Bagaimana pun katil dan kawan-kawan telah menyajikan sebuah penawaran sajian kolaborasi teater yang berimbang (Gong, edisi 96/2007).

\section{Hikayat Cantoi}

Penulis hikayat Cantoi sangat tertarik dengan gerak dasar seudati, apabila gerak tersebut dapat diterima menjadi blocking dalam konsepsi pertunjukan teater. Hal ini akan terjadi kebaruan di dunia teater modern Indonesia. Begitu juga kekuatan sastra Aceh baik lewat didong maupun hikayat dapat menjadi aturan/hukum bagi masa depan teater Indonesia.

Berdasarkan itu, sulaiman mengawinkan konsepsi teater tradisi dengan teater modern untuk memuliakannya. Cantoi merupakan saksi sejarah atas peristwa yang menimpa Aceh, dan tokoh Cantoi merupakan wakil dari rakyat Aceh, terpaksa pintar-pintar bodoh untuk menyuarakan ketertekanan batin yang mengapung di jiwa agar jadi catatan sejarah untuk pembelajaran bagi masa depan. Namun sudah merupakan sikap dan sifat manusia jika rasa takut memuncak maka muncullah keberanian cantoi untuk melawan.

Naskah ini memiliki isu kekuasaan sangat akrab dengan kejahatan. Hikayat Cantoi merupakan sebuah karya monolog yang menceritakan peristiwa yang terjadi di Aceh dalam masa konflik antara negara kesatuan republk IIndonesia (NKRI) dengan gerakan Atjeh Merdeka (GAM) di Aceh. Hikayat cantoi di tulis dengan maksud sebagai sentilan pada pemerintah pada masa itu maupun masa kini.

Bentuk garapan yang digunakan dalam pertunjukan Cantoi adalah bahasa yang digunakan dalam pertunjukan ini menggunakan Bahasa Indonesia. Namun dibeberapa adengan untuk membangun suasana tetap mengunakan bahasa Aceh, salah satunya di awal dan di akhir pertunjukan mengunakan nyanyian hikayat prang sabi (kisah/cerita perang suci). Sementara lagu Atjeh Tanoeh Loen Sayang dan lagu Sebuku (ratapan) dan untuk musik sutradara menggunakan tari saman yang menggunakan tubuh sebagai media suara yaitu dengan cara di tepuk sesuai dengan pola dan irama yan diinginkan.

\section{Proses kreatif Hikayat Cantoi}

Hikayat Cantoi merupaka karya Sulaiman Juned yang dapat dikatakan sebagai sebuah ekspresi estetik sulaiman yang berhubungan dengan realitas sosial Aceh pada masa konflik NKRI dan GAM yang pernah disaksikannya. Teks drama Hikayat Cantoi seolah menyajikan secara simbolis kenyataan yang dialami masyrakat Aceh pada masa konflik bersenjata yang terjadi pada tahun 19891998. Selain fenomena yang terjadi di Aceh ternyata pada masa itu adalah masa orde baru yang otoriter yang menyebabkan banyaknya terjadi kerusuhan di seluruh Indonesia.

Hal ini menjadi dasar pemikiran bahwa konflik Aceh sebenarnya hanya sekedar personifikasi bagi seluruh masalah represifitas yang terjadi di Indonesia di masa orde baru. Dasar inilah menjadi pemikiran, maka Cantoi adalah penggambaran wajah orang Indonesia di masa orde baru. Wajah ketertekanan secara politik dan ketakutan secara psikologis terkait kerasnya pendekatan yang dilakukan pemerintah dalam 
melakukan penyelesaian konflik sosial masyarakat pada tahun itu, hal ini lah yang menjadi lahirnya naskah Cantoi dengan tradisi Aceh, tetapi ditampilkan dalam bentuk teater modern yang bahkan naskah tersebut masih menyentil kehidupan politik masa kini.

Proses kreatif Hikayat Cantoi berasal dari keinginan sutradara menggarap teater monolog yang berbasis dari teater tutur Aceh P.M.T.O.H. Jadi, penulis dalam hal ini tidak berangkat dari naskah hikayat melainkan menulis naskah monolog yang berjudul Hikayat Cantoi yang di pentas dengan Bahasa Indonesia serta mengabungkan konvensi (Aturan/ Hukum) teater modern terutama pada movement (pergerakan), dan blocking (perpindahan) pemeran di atas pentas, seting (dekorasi), proferti, rias, dan busana. Juga memakai kekayaan tubuh sebagai musik (musik perkusi tubuh), seperti; tepuk dada, paha, perut, dan ketip jari (seudati), tepuk tangan (didong), rabana adok, serta gerak tari guel.

Seudati merupakan suatu bentuk teater tradisional Aceh yang struktur dasarnya ada gerak, syair dan dimainkan seluruhnya oleh laki-laki. Guel sebenarnya sendratari yang ditarikan oleh beberapa penari wanita dan seorang penari laki-laki dengan gerak patahpatah. Tari ini untuk membangunkan gajah jelmaan dari seorang anak raja yang sudah meninggal, dan dipercayakan oleh masyarakat Aceh, gajah jelmaan tersebut menjadi gajah putih tunggangan Sultan Iskandar Muda. Didong teater tradisional Aceh yang kekuatannya terdapat pada syair (cerita yang berbentuk puisi), tepuk tangan dan goyangan badannya dengan pola duduk melingkar.

\section{PENUTUP}

Kehadiran seni pertunjukan teater modern di Indonesia tidak terlepas dari sejarah kehadiran seni pertunjukan teater di Indonesia. Istilah modern merujuk pada situasi dalam ruang dan waktu masa kini. Hal ini merupakan cara menunjuk adanya perkembangan dan perubahan teater di daerah-daerah menjadi bentuk teater kekinian yang bercita rasa Indonesia. Artinya terjadi pergeseran konteks cipta, rasa, karsa, dari kehendak seniman yang bersifat tradisional menjadi kehendak yang bersifat nasional.

Setiap perwujudan bentuk dan isi teater, memiliki ciri-ciri bentuk dengan kecenderungan-kecenderungannya yang khas. Perkembangan, perwujudan teater mengalami indentifikasi hingga menjadi genre teater. Oleh karena itu, terjadinya perubahan di berbagai bentuk teater. Bentuk teater yang sudah ada kemudian dianggap tidak lagi memadai untuk menjawab kebutuhan teater di zamannya. Seniman teater selalu bereaksi terhadap bentuk teater yang sudah ada itu dan melahirkan suatu bentuk teater yang baru. Proses perkembangan yang terjadi di Indonesia menyebabkan teater-teater tradisonal bertransformasi menjadi bentuk-bentuk teater baru. Kebaruan teater tersebut pada masanya mengikuti konvensi dari Barat. Hasil dari proses silang budaya inilah yang menjadi cikal bakal lahirnya teater modern yang ada di Indonesia. Perkembangan teater tradisional mulai terkikis ciri khas ketradisionalnya, sebagai akibat akulturasi budaya teater modren. Namun ada juga komunitas yang yang menjadikan tradisi sebagai landasan dalam mengembangkan teater modern.

Penelitian dideskripsikan sebagai suatu proses investivigasi yang dilakukan 
dengan aktif, tekun, dan sistematis.

Penelitian ini bertujuan, menginterpretasikan, dan merevisi faktafakta. Berdasarkan penjelasan tersebut penulis berniat untuk meneliti perkembangan teater modern Indonesia berbasis tradisi di kota Padangpanjang.

Berdasarkan hal di atas penulis menjadi tertarik untuk melakukan penetian tentang perkembangan teater modern Indonesia berbasis tradisi di kota Padangpanjang. Informasi serta hasil Analisa dari penelitian tersebut dapat dijadikan sebagai dasar landasan melihat perkembangan teater di kota padangpanjang pada penelitian ini. Penelitian untuk mendapatkan berbagai pola aktifitas yang intensif dari komunitas teater di kota Padangpanjang.

Penulis tertarik untuk melakukan penelitian ini dikarenakan perkembangan teater modern Indonesia di Padangpanjang yang signifikan. Hal ini dibuktikan dengan adanya dua komunitas teater yang aktif yang telah terlibat pada kancah kancah nasional. Kehadiran dua Komunitas teater ini mampu membawa Padangpanjang ke kancah nasional, dan dua komunitas ini memiliki ciri khas dari kampung halaman penyaji atau sutradara yaitu tradisi minagkabau dan tradisi aceh.

Sesuai dengan penjabaran di atas bahwa komunitas seni Hitam Puth dan komunitas seni Kuflet adalah dua komunitas yang beberapa karya masih mempunyai ciri khas dari kampung halaman masing-masing sutradara. Komunitas yang masih mempertahan sisi tradisinya tetapi tetap fleksibel dengan perkembangan zaman sekarang. Ideologi politik, perkembangan sosial budaya, dan proses perkembangan globalisasi, berhasil di jadikan tombak dalam mengahadapi perkembangan di dunia teater modern oleh kedua kemunitas ini.

\section{DAFTAR PUSTAKA}

Aritonang, Robert dkk. (2008). Orang

Rimba Menentang Zaman, Jakarta:

WARSI

Dillistone, F, W. 1986. The Power Of Symbols. Terjemahan A. Widayamartaya.

Daya Kekuatan Simbol. Yogyakarta : Kanisius

Hadi, Sumandiyo. 2003. Koreografer Kelompok. Yogyakarta: Pustaka

Hidayat, Robby. 2011. Koreografi dan Kreatifitas. Yogyakarta : Media Kendil.

Padmodarmaya, Pramana, 1988, Tata Dan Teknis Pentas. Yogyakarta Pustaka Book.

Merina, Raflesia. 2013. Rimba Abu-Abu. Laporan Karya Tugas Akhir Pasca Sarjana. Padangpanjang : ISI Padangpanjang.

Putra, Mahardhika, Tri. 2016. Ukar Delom Bungen. Laporan Karya Tari. ISI Padangpanjang.

Sharma, Arvind. 2002. Perempuan Dalam Agama-Agama

Dunia. Perguruan Tinggi Agama Islam Depertemen Agama RI.

Sastra, Andar, Indra, 2018, Suku Melayu: Sistem Matrilineal dan Budaya Perunggu di Minangkabau. Jurnal Melayu Art And Performance Journal. Vol. 1, No. 1, April, 2018

Smith, Jacquelin. 1985. "Dance Composition" A Practical Guide for teachers. Terjemahan Ben Suharto. Komposisi Tari" Sebuah Petunjuk Praktis bagi Guru. 
Yogyakarta : Ikalasti.

Susanto, Edi. 2014 Dimensi Studi Islam Kontemporer.Surabaya: CV Salsabila.

Triyuliani, Lovia. 2019. Mutualisme. Sebuah Karya Tari Yang Terinspirasi

Dari Fenomena Sosial Masyarakat pengguna jamban Di Muaro Bungo. Jurnal Melayu Art And Performance Journal. Vol.2, No. 1. April.2019. 